\title{
Assessment of level of mechanization in selected crops of north Karnataka
}

\section{P. NAGARJUNA REDDY, JAGADEESH G. ANGADI AND S.R. DESAI}

Received : 31.05 .2017 ; Revised : 15.08.2017; Accepted : 29.08.2017

See end of the Paper for authors' affiliation

Correspondence to :

P. NAGARJUNA REDDY

Department of Agricultural Extension Education,

University of Agricultural

Sciences, DHARWAD

(KARNATAKA) INDIA

Email : nagarjun912@gmail.

com
-ABSTRACT : The level of agricultural mechanization for each field operation in different crops of North Karnataka were measured and analyzed. The purpose of the study was to determine the level of mechanization for each field operation in paddy, maize and pigeonpea crops. Data were collected from a sample of 240 farmers in which paddy, maize and pigeonpea growers constituted 80 each. Tillage/land preparation operations such as ploughing, harrowing and other field operations (puddling, leveling and clod crushing) and threshing operation had high level of mechanization compared to operations like sowing/transplanting, weeding and harvesting. Deficit or nonavailability of sufficient farm machinery with the farmers was observed. In order to solve this problem, the availability of implements/machinery, skilled labours and repair centers should be increased for timeliness of operation.

- KEY WORDS : Level of mechanization, Paddy, Maize, Pigeonpea

- HOW TO CITE THIS PAPER : Reddy, P. Nagarjuna, Angadi, Jagadeesh G. and Desai, S.R. (2017). Assessment of level of mechanization in selected crops of north Karnataka. Internat. J. Agric. Engg., 10(2) : 457-460, DOI: 10.15740/HAS/IJAE/10.2/457-460. 